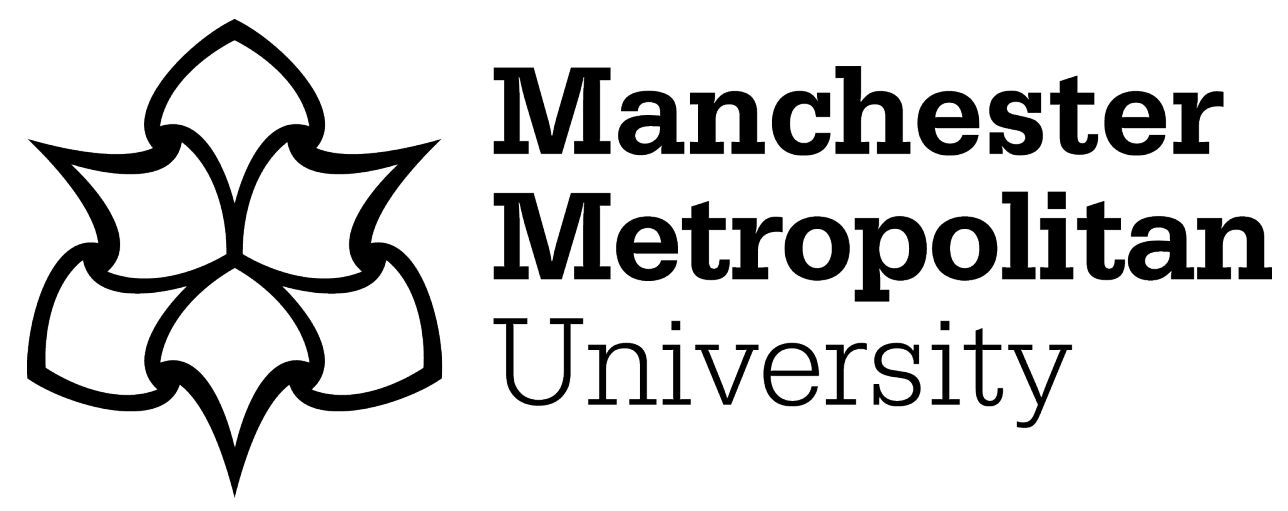

Vanderschelden, Isabelle ORCID logoORCID: https://orcid.org/0000-00021566-5246 (2020) Book Review: French blockbusters: cultural politics of a transnational cinema. Modern and Contemporary France, 28 (3). pp. 352353. ISSN 0963-9489

Downloaded from: https://e-space.mmu.ac.uk/626179/

Version: Accepted Version

Publisher: Taylor \& Francis (Routledge)

DOI: https://doi.org/10.1080/09639489.2020.1769047

Please cite the published version 


\section{French blockbusters: cultural politics of a transnational cinema MICHAEL, Charlie}

Edinburgh: Edinburgh University Press. 2019

256 pp., $£ 75.00$ (hardback), ISBN 978-1-4744-2423-3

For a number of years now, Charlie Michael has been exploring the cultural paradoxes of French blockbusters, questioning their place within the French film industry, their international reception and the policies underlying their production. He defines the 'French blockbuster' as 'delinked from nationality and place-ness designating a type of filmmaking that arose [...] to exceed national specificities by design, often doing so through ties with corporate business culture, formulaic and 'universalist themes and digitised special effects' (13). While establishing bridges between Hollywood and a significant international strand of French cinema, the association of 'French' and 'blockbuster' is presented as a contradiction in terms. This is one of the mild provocations underlying an original book in English that offers fresh readings of the local/global and popular/art cinema tensions found in the French industry, often adopting a comparative approach (combining for example French perspectives and those of AngloAmerican audiences and film scholars).

Michael proposes a welcome synthesis of efforts made to reconcile the commercial and transnational trends of the last thirty years with the local specificities of France's film industry and its identity. He sets out to historicise the perennial legacy of the 'Lois Lang' in the 1980s showing that these laws were at the origin of a strategic cultural model adopted to produce super-productions which were at once attractive to the world market and competing with Hollywood's supremacy. His methodological proposal to tackle French blockbusters with the three paradigms of 'exceptionalist, professionalist and pragmatist' (60) helps to address the problematic denomination of 'popular' cinema (often used in inverted commas in the book) and opens up new avenues to address the diversity of the corpus used.

The issues raised by French blockbusters identified by Michael justify revisiting a few canonised blockbusters of the 1990s and early 2000s such as heritage super-productions (Germinal Berri, 1993) and 'social phenomenon' films like Jeunet's Amelie (2001) and Intouchables (Nakache and Toledano, 2011) in a different light. Drawing on transnational trends and French cultural politics, they all illustrate how France has negotiated the transition to the $21^{\text {st }}$ century's new modes of production and consumption to remain present on the global market and improve its international visibility.

Adopting a case study approach, the author unsurprisingly devotes several sections to Besson's European major EuropaCorp, whose international hits include the Taxi and Transporter franchises, the Taken trilogy, and of course, Lucy (Besson, 2014). Michael stops to consider the reasons behind the gamble of the recent oversized project of Valérian (Besson, 2017), illustrating the limits of balancing ambitious spectacle and culture-specific material. Using other examples-action movies, the niche of parkour action films, and comedies-he maps out different genre and production models for French blockbusters, drawing attention to cultural and ideological affiliations which generated debates in France, but remained largely unnoticed outside France. 
More generally, the wide-ranging case studies inform the reader on commercial issuespleasing those looking for statistics on the French film industry and an insight into commercial trends, but they also address how broader economic strategies and cultural policies going beyond generic conventions and commercial success come into play. It is significant that the film choices should be organised around specific production models-and influential producers or directors who reinvent the genres traditionally associated with blockbusters-comedies and heritage films, but also others less readily associated with the local tradition (martial arts, science fiction). Mainstream comedies like Intouchables, Qu'est-ce qu'on a fait au Bon Dieu (Chauveron, 2014) and Les Tuche (Baroux 2011, 2016 and 2016) are unsurprisingly included into the discussion alongside EuropaCorp franchises. Less predictably, the book ends on a blockbuster reading of Des hommes et des dieux (Beauvois, 2010) which aptly illustrates the ambivalence of the film industry's diversity and the limits of the French blockbuster renegotiating its local culture in a global age, which in my view is one of the strengths of the book.

Beneath its provocative title, French Blockbusters convincingly reaffirms the vitality of the commercial strand French cinema and its presence worldwide, even if does not always reconcile the contradictions inherent to its subject matter. In addition, the expectations of international audiences are bound to affect the global reception of some French blockbusters. No wonder that some have occasionally been-and will remain-at the mercy of cultural and ideological interpretations or misunderstandings. If Michael's book successfully maps out the conscious efforts of the French film industry for more visibility without losing some of its identity, the pragmatic responses identified in this volume may well be needed in light of the cultural crisis of 2020, which no doubt will change the rules and require new policies and dynamic changes yet again.

Isabelle Vanderschelden Manchester Metropolitan University, Manchester, UK

Qi.vanderschelden@mmu.ac.uk

(c) 2020 Isabelle Vanderschelden https://doi.org/10.1080/09639489.2020.1769047 